\title{
Impact of anthropic activities on the geographic landscapes' state in the area of Republic of Moldova in XXI century.
}

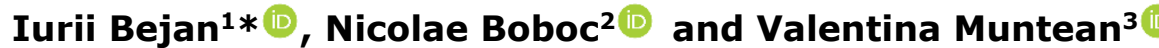 \\ 1 Institute of Ecology and Geography, Chișinău, Republic of Moldova, iurie.bejan@gmail.com \\ 2 Institute of Ecology and Geography, Chișinău, Republic of Moldova, nicboboc@gmail.com \\ 3 Institute of Ecology and Geography, Chișinău, Republic of Moldova, valik65@gmail.com \\ * Correspondence: iurie.bejan@gmail.com; Tel.: +373-695-86-429 (B.I.)
}

Keywords: landscape, commune, population density, naturality index, environmental change

\begin{abstract}
Considerable anthropization degree of environment during the modern period had determined a gradual sinking of ecological stability of geographical landscapes, especially given the predominance of agricultural landscapes which occupy $73.4 \%$ from total area of Republic of Moldova at present. Land Cadaster data for Republic of Moldova (2000-2020) and population level's statistical data (2000-2019) was used to obtain a few indicators that reflect the state of geographical landscapes (population density, naturality index and environmental changes index) and quantify the anthropic pressure on the geographical landscapes at the commune level. We had used the period of 2000-2020 as the reference period.
\end{abstract}

\section{Introduction}

Republic's contemporary natural landscapes have evolved in parallel with human appearance and evolution. The essential changes of the natural environment under the influence of anthropogenic activities have contributed to the deterioration of landscapes' state. The natural landscapes' changes and the anthropogenic load's increase not only have contributed to the decrease of the ecological stability of the territory, but also to the degradation of the environment in general.

Some authors (Muchová, Tárníková, 2018) consider that 1.5-2 ha of land per capita is needed to ensure optimal human existence in the case of developing countries from the temperate zone, which practice subsistence agriculture. This area is necessary to meet all vital needs - housing, industrial and agricultural products, leisure, etc. In the Republic of Moldova, on average, 1 person has 0.96 ha of land (Cadastrul funciar al Republicii Moldova pentru anul 2020 si perioada 2001 - 2020; Baza de date statistice Moldova). This explains increased anthropogenic load on the environment and requires the immediate resolution of land use issues.

It is crucial to carry out quantitative assessments to develop an optimal landscape management system and to monitor the current changes in land use. Among these assessments, it is of particular interest to estimate the state of landscapes based on indicators of anthropogenic load - population density, index of landscapes' naturality and environmental changes index. 


\section{Materials and Methods}

To estimate the degree of the human-induced transformations we had selected naturality index, environmental change index and the population density as most representative ones.

Population density represents the ratio between the population size at a given moment and the area of the territory inhabited by it (as a rule, per $1 \mathrm{~km}^{2}$ ) (Erdeli et al., 1999). The analysis of the population density presents a special interest in the organization of the territory and the systematization of the localities, in the management of the production for consumption, in the dimensioning and modelling of the tertiary sector. What this indicator in fact shows us is the anthropogenic pressure on the geographical landscapes and land use categories per capita population/land use rating.

Landscape's naturality index represents the ratio between the area covered by the forest and the analyzed area to which it relates, starting from the idea that the forest is an important factor of environmental balance (Vijulie, 2010):

$$
I_{\text {nat }}=\left(S_{\text {forest }} / S_{\text {total }}\right) \times 100
$$

Environmental change of the landscapes is calculated as the ratio between the area occupied by forests and meadows to the area occupied by buildings (Maruszczak version), reflects the landscapes' anthropic change intensity (Simulescu, 2018).

$$
I_{E . C h . M}=S_{\text {forest }}+S_{\text {meadow }} / S_{\text {buildings }}
$$

However, the biggest change in the structure of the original landscapes was caused by agricultural activity. Thus, $M$. Dumitrașcu [8], adapted this index to the real conditions in the Oltenia Plains (which are similar to those in the Republic of Moldova), introducing in the formula several categories of agricultural landscapes (arable land, orchards and vineyards). Thus, the modified formula of the environmental change index is:

$$
I_{E . C h . D}=S_{\text {forest }}+S_{\text {meadow }}+S_{\text {water }} / S_{\text {buildings }}+S_{\text {arable }}+S_{\text {vineyards }}+S_{\text {orchards }}
$$

\section{Results and discussions}

Population density $\left(D_{p}\right)$ was in constant decline during the last two decades (Figure 1), which also conditioned the mitigation of the human-induced impact on the landscapes. The population density index had declined from 108 inhabitants $/ \mathrm{km}^{2}$ in year 2000 to the $98 \mathrm{inh} . / \mathrm{km}^{2}$ in 2019. The decrease of the population density index during this period was caused both by the negative values of the natural increase and by the negative net migration rate. Thus, the human population in the last two decades has decreased by 328.6 thousand of inhabitants. We also should mention that in 1990 the population of the Republic of Moldova was 4361.6 thousand inhabitants, and the population density was $129 \mathrm{inh} . / \mathrm{km}^{2}$. Hence, the population of the Republic of Moldova has decreased by over 1 million of inhabitants or by about $25 \%$ during the 30 years of independence (Baza de date statistice Moldova).

The main spatial differences of population density are caused by the historical factors of population and colonization of this territory (southern part of Transnistria, ATU Gagauzia, Taraclia region); by the economic ones (high density in the periurban areas around the municipalities of Chisinau, Tiraspol, Tighina, Balti) and by the favourable geographical position (along rivers, roads, etc.). 


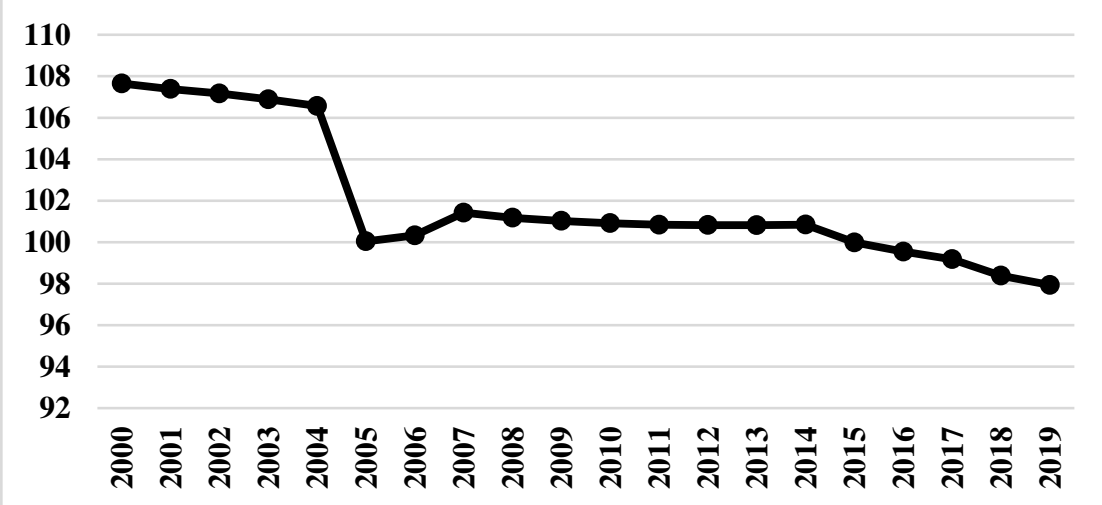

Figure 1. Dynamics of the population density index (inh. $/ \mathrm{km}^{2}$ ) of the Republic of Moldova during the period of 2000-2019

The population density currently varies spatially from $1 \mathrm{inh} . / \mathrm{km}^{2}$ in the commune of Pervomaisc (ATU on the left bank of the Dniester River) to 5,196 in the municipality of Tighina. Out of the whole 143 communes in which the population density does not exceed $40 \mathrm{inh} . / \mathrm{km}^{2}, 40$ are in the Dniester's left bank area's ATU (including all communes with population density values less than $10 \mathrm{inh} . / \mathrm{km}^{2}$ ). Low values are also recorded in the southern part - in the regions of Cahul, Leova, Cimișlia and ATU Gagauzia (Figure 2). A depopulation during the period of 2000-2019 is registered in some communes in the northern part, which happen to contain the locations isolated from the main communication routes and with a pronounced agrarian profile - Ocnița, Dondușeni, Râșcani and Drochia regions. High values of population density are maintained in the central part of the republic, where Chisinau City continues to be a polarizing center.

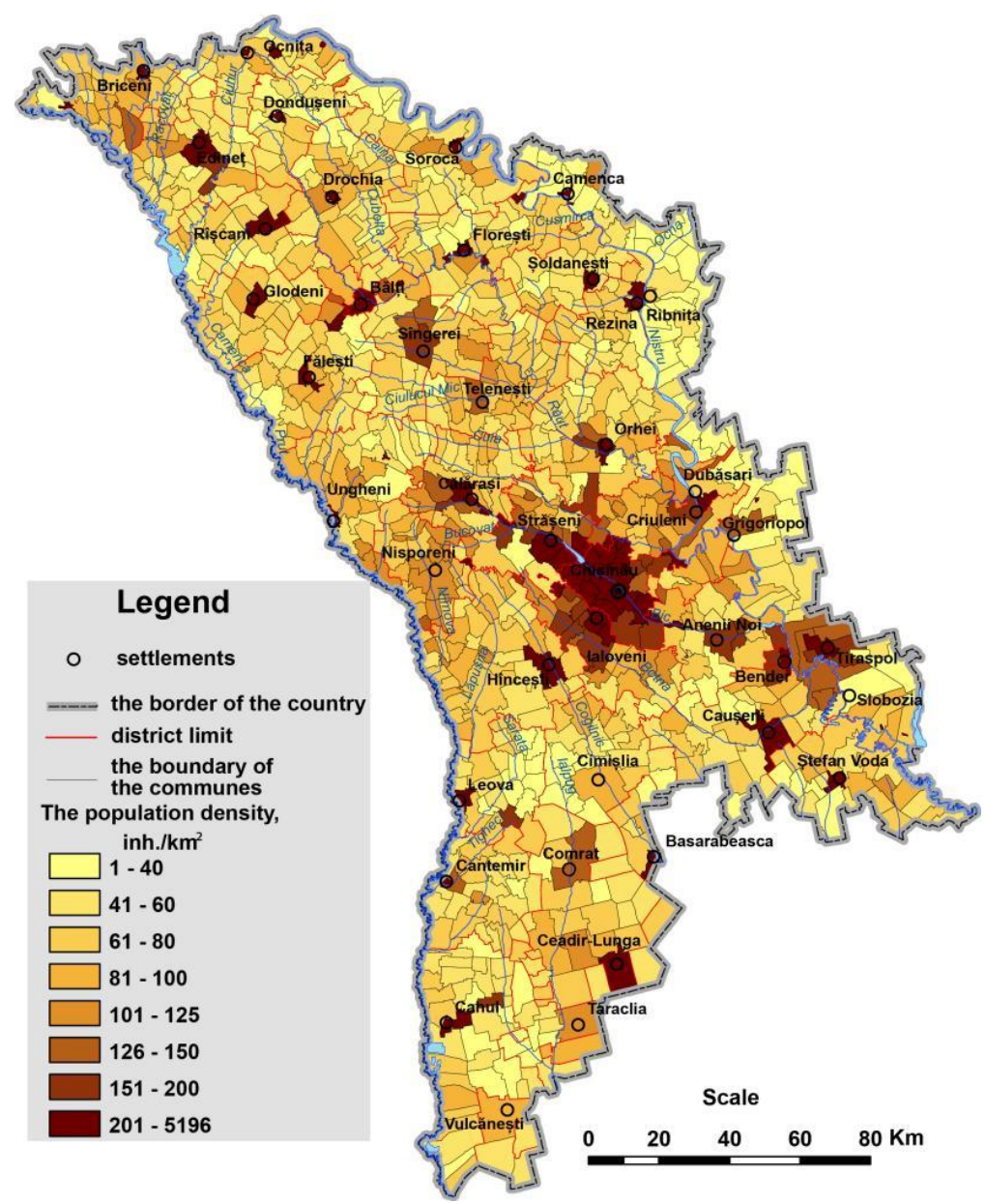

Figure 2. Spatial distribution of the population density (inh. / $\mathrm{km}^{2}$ ), 2019 
Landscape naturality index ( $\mathrm{I}_{\text {nat }}$ ) represents the ratio between the total value of the forests area and the green belts to the total area of the spatial unit (thus determining the degree of afforestation). Considering the values obtained from the calculation of this index, some authors (Ionuș et al., 2011) had classified the degree of damage to the landscape into 6 categories:

- landscapes close to the original ecological balance $(>0.60)$.

- landscapes with a relatively stable ecological balance (0.45-0.60).

- landscapes with a slightly affected ecological balance (0.30-0.45).

- landscapes at the limit of ecological balance (0.20-0.30).

- landscapes with heavily affected ecological balance (0.10-0.20) and

- landscapes with extremely affected ecological balance $(<0.10)$.

Other authors (Boboc et al., 2020) had been assessing the value of Inat (on the example the Cogâlnic river basin) by classifying the degree of landscape damage also in the six categories of landscapes, with some small differences in the values of the first two categories:

- landscapes with the ecological balance close to the original ( $>0.50)$.

- landscapes with a relatively stable ecological balance (0.40-0.50).

We had identified the following categories of landscapes as a result of our calculation of the I nat values based on data (Population data - Baza de date statistice Moldova):

- with extremely affected ecological balance $(<0.10)$.

- with heavily affected ecological balance (0.11-0.20).

- at the limit of ecological balance (0.21-0.30).

- with a slightly affected ecological balance (0.31-0.40).

- with a relatively stable ecological balance (0.41-0.50).

- close to the original ecological balance (0.51-0.79).

The average value of the naturality index $I_{\text {nat }}$ in the Republic of Moldova was 0.123 at the beginning of 2020, decreased compared to 2000 (0.125). Most of the areas on the left bank of the Dniester (communes in Râbnița, Dubăsari, Grigoriopol and Slobozia regions) fall into the category of the landscapes with extremely affected and heavily affected ecological balance, which is also true for most of the communes situated on the southern plains of the Prut-Dniester interfluve (ATU Găgăuzia, Basarabeasca, Ștefan-Vodă). The communes from the lower parts of Cubolta Plains and the middle parts of Prut River, most of the Ciuluc Hills area (Sangerei and Telenesti regions, the western part of Floresti region, the eastern parts of Falesti region, etc.) fall into the same category as mentioned above. Only 14 communes belong to the category of landscapes close to the natural ones, 8 of them are in the Codri Plateau: including three from the Straseni region (Căpriana has the highest value of $I_{n a t}$ in Republic of Moldova (0.790); Lozova and Scoreni); three communes from Hâncești region (Stolniceni, Mereșeni, Bălceana); and one commune in each of the following regions: Călărași (Buda), Ungheni (Rădenii Vechi) and Ialoveni (Cigârleni). Two communes from Orhei region (Teleșeu and Vatici) are also assigned to the above-mentioned category, one is from the Northern Moldavian Plateau (Briceni region - Slobozia-Șirăuți commune) and another is from the left bank of the Dniester River (Rotari commune, Camenca region). The category of landscapes with relatively stable ecological balance is represented by 15 communes, 12 of them belong to the area of Codri Plateau: Călărași region (Vărzăreștii-Noi, Pitușca, Răciula, Frumoasa, Bravicea, Hârjauca communes, etc.), Chisinau municipality (Vadul lui Vodă town), Hâncești region (Mirești and Buțeni communes), Ialoveni region (Cărbuna commune). Băiuș commune from Leova region and Hârbovăț commune from Anenii Noi region are also attributed to this category of landscapes (Figure 3 ).

The category of landscapes at the limit of ecological balance is more widely represented in the plateau areas, less numerous in the lowlands, but also in several 
plains' areas, where forest landscapes are represented by pockets of "ditch forests"(Ionuș et al., 2011). The number of landscapes at the limit of the ecological balance is over 90 communes, including 35 communes in the Codri Plateau area. In the Dniester Plateau, there are also areas of forest landscapes at the limit of ecological balance. We also mention the presence of this category of landscapes in the communes of Ciuluc Hills area.

The classification of landscape units in relation to the value of the Naturality Index (Inat) has scientific value as well as significant applicable aspect. These categories can serve as a support in the process of developing a differentiated system of landscape protection measures (for example, identification of land for afforestation), in relation to landscape categories by $I_{\text {nat }}$ value.

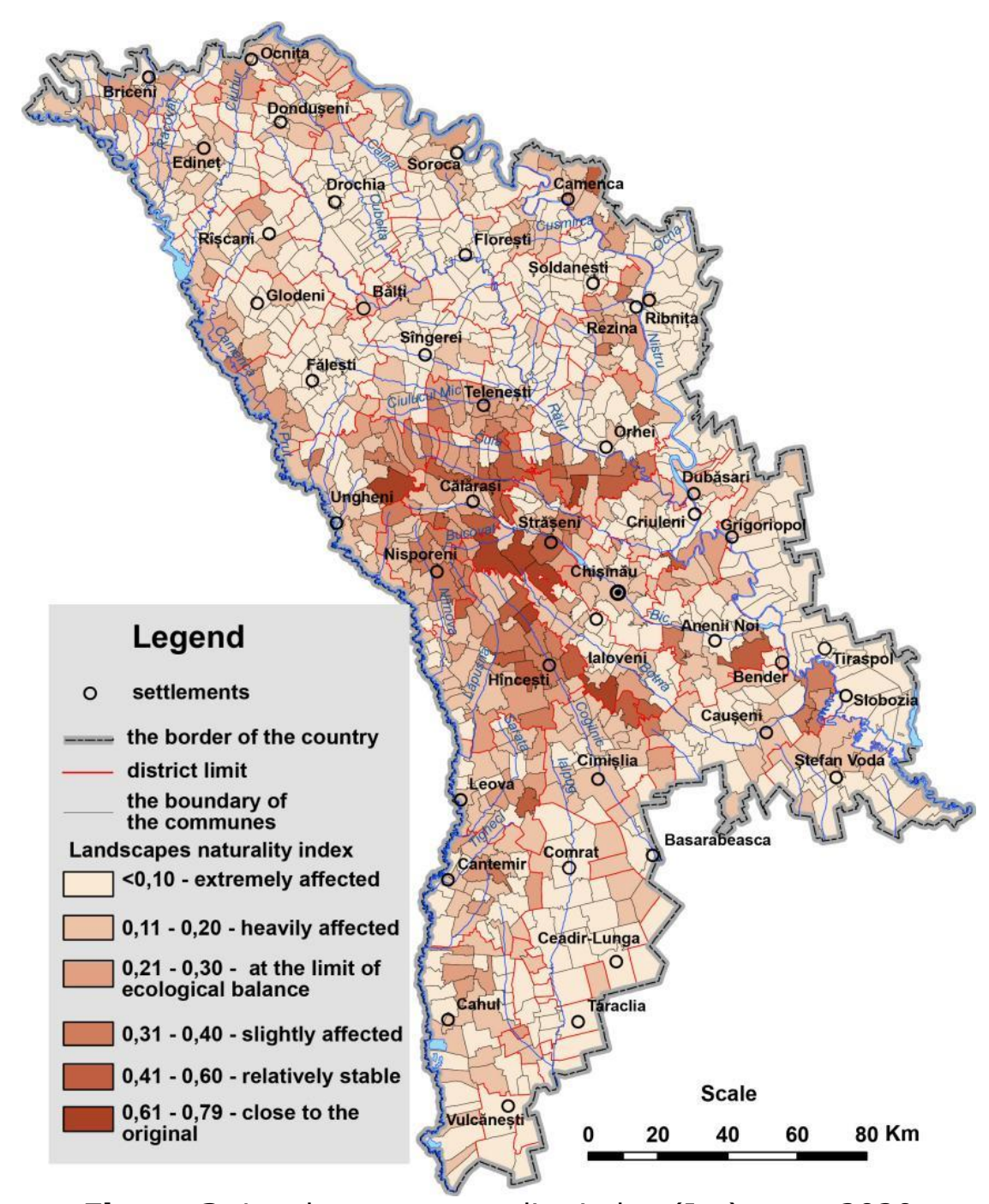

Figure 3. Landscapes naturality index ( $\left.I_{\text {nat }}\right)$, year 2020

A qualitative characterization of the state of the landscapes can also be obtained using the Index of environmental change of landscapes ( $\mathrm{I}_{\mathrm{E} . \mathrm{Ch} . \mathrm{M}}$ ), which is estimated as the ratio of land area with natural landscapes (forest and meadows) to lands with buildings (anthropogenic or entirely modified). The average value of the IE.Ch.M in 2000 it was 3.4, and by 2020 it decreased to 3.16 (extremely transformed landscapes). The decrease of the share of natural landscapes in the period 2000-2020, in relation to the built area, was registered in the municipalities of Chisinau and Balti, but also in the localities from Cahul, Dubasari, Ialoveni, Ocnita regions and ATU Gagauzia. 
The extremely transformed landscapes predominated making up to $52.7 \%$ and the heavily transformed ones $-23 \%$ at the beginning of 2020 , as during the whole analysed period. Thus, over $3 / 4$ of the communes of Republic of Moldova represent territories with extreme and heavy environmental transformations, $10.9 \%$ with moderate environmental transformations and insignificantly transformed landscapes are in only $3.2 \%$ of the communes (Figure 4). The last category of landscapes (relatively transformed) is represented by 31 communes, most of them being located within the Codri Plateau (Ungheni region - Rădenii Vechi commune, Hâncești region - Bobeica and Bălceana communes, Ialoveni region - Cigârleni commune, Călărasi region - Buda and Vărzăreștii Noi communes); less often, in the spaces of nature reserves in the lowland regions (Padurea Domneasca in the Middle Prut Plains area). There are also several landscape units with IE.Ch.m values of over 50 in the Ciuluc Hills area (Telenești region with Crasnoșeni, Văsieni and Zgărdești communes).

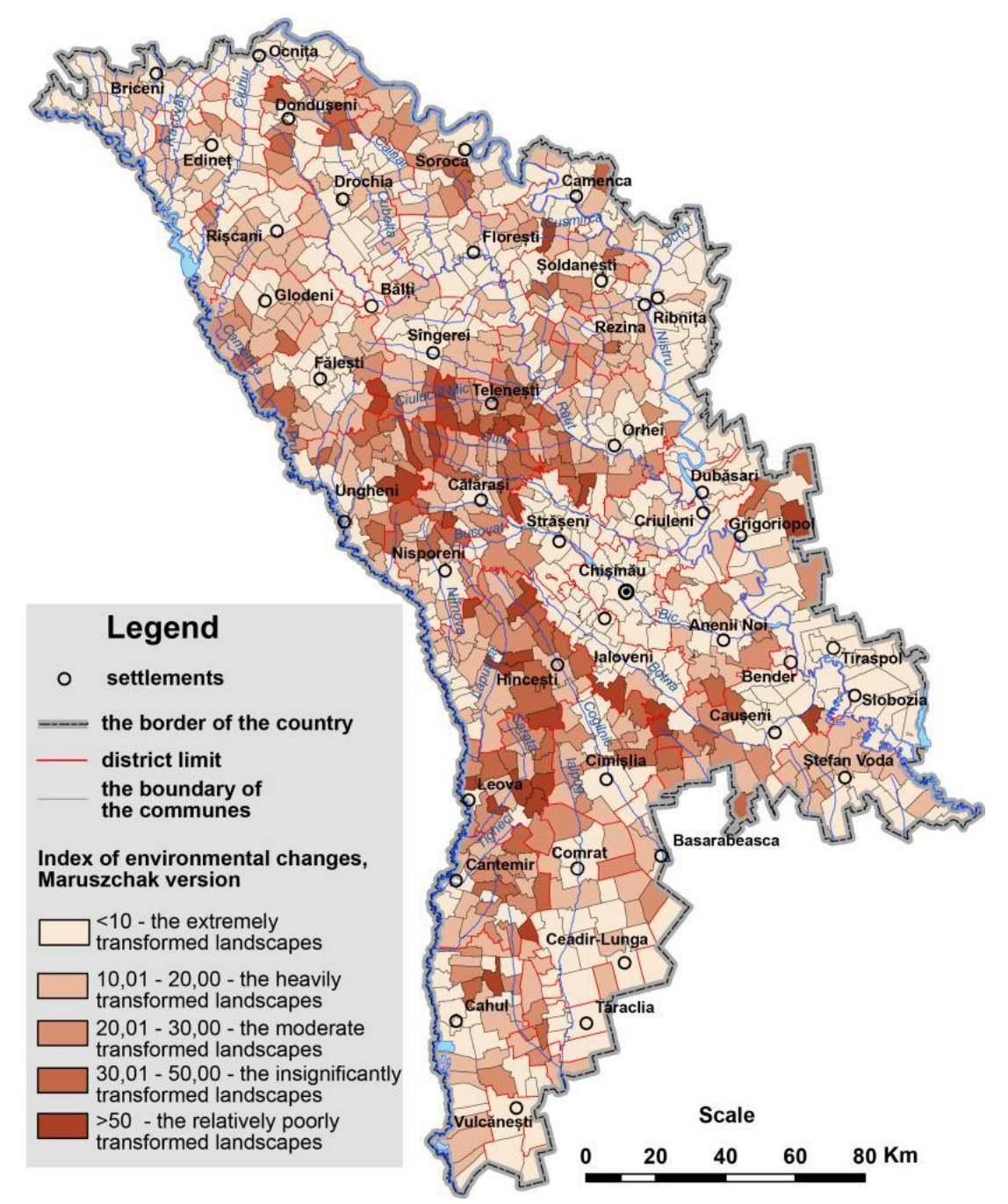

Figure 4. Index of environmental changes, Maruszchak version (IE.Ch.M), 2020

The above-mentioned category of landscapes is present in the southern part of republic in the Causeni region (Plop-Știubei and Chircăieștii Noi communes).

In the Tigheci Hills, the landscapes with insignificantly transformed environment are present in Leova region (Sârma, Băiuș, Romanovca communes, etc.) and Cahul region (Tătărești and Câietu communes). 
The landscapes with slight environmental transformation were identified in 69 communes ( $7 \%$ of the total number), including 20 communes from the Codri Plateau area.

Based on the fact that the biggest change in the structure of the initial landscapes was caused by agricultural activity, the assessment of the Index of the Environmental Change, proposed by M. Dumitrașcu (Sencovici, Pehou, 2016) (IE.Ch.D), shows the level of anthropogenic load on geographical landscapes more objectively.

The average value of the IE.Ch.D in 2000 was 0.38 , and by 2020 it decreased non-essentially -0.36 . Decrease of the value of $\mathrm{I}_{\mathrm{E} . \mathrm{Ch} . \mathrm{D}} \mathrm{had}$ been caused by the reduction of the areas covered with forests (by 6.5 thousand ha) and meadows (by 40.5 thousand ha) on the one hand and also by the extension of the areas occupied by arable land (by 17.8 thousand ha) and of those occupied by buildings (by 3.9 thousand ha). In 2020, as during the whole analyzed period, the moderately affected landscapes predominate ( $\mathrm{I}_{\text {E.Ch.D }}=0.26-0.5$ ) making up to $41.6 \%$ and the landscapes with completely and extremely affected ecological balance $\left(\mathrm{I}_{\mathrm{E} . \mathrm{Ch} . \mathrm{D}}<0.25\right.$ ) make up to $30.5 \%$. Thus, over $72 \%$ of the communes of the Republic of Moldova represent the territories with environmental transformations from moderate to complete, i.e extremely affected by anthropogenic changes. According to the calculations, the most affected are the landscapes in the Administrative Territorial Unit on the Left Bank of the Dniester, where there are 15 communes with completely affected landscapes and 27 communes with extremely affected landscapes (Figure 5).

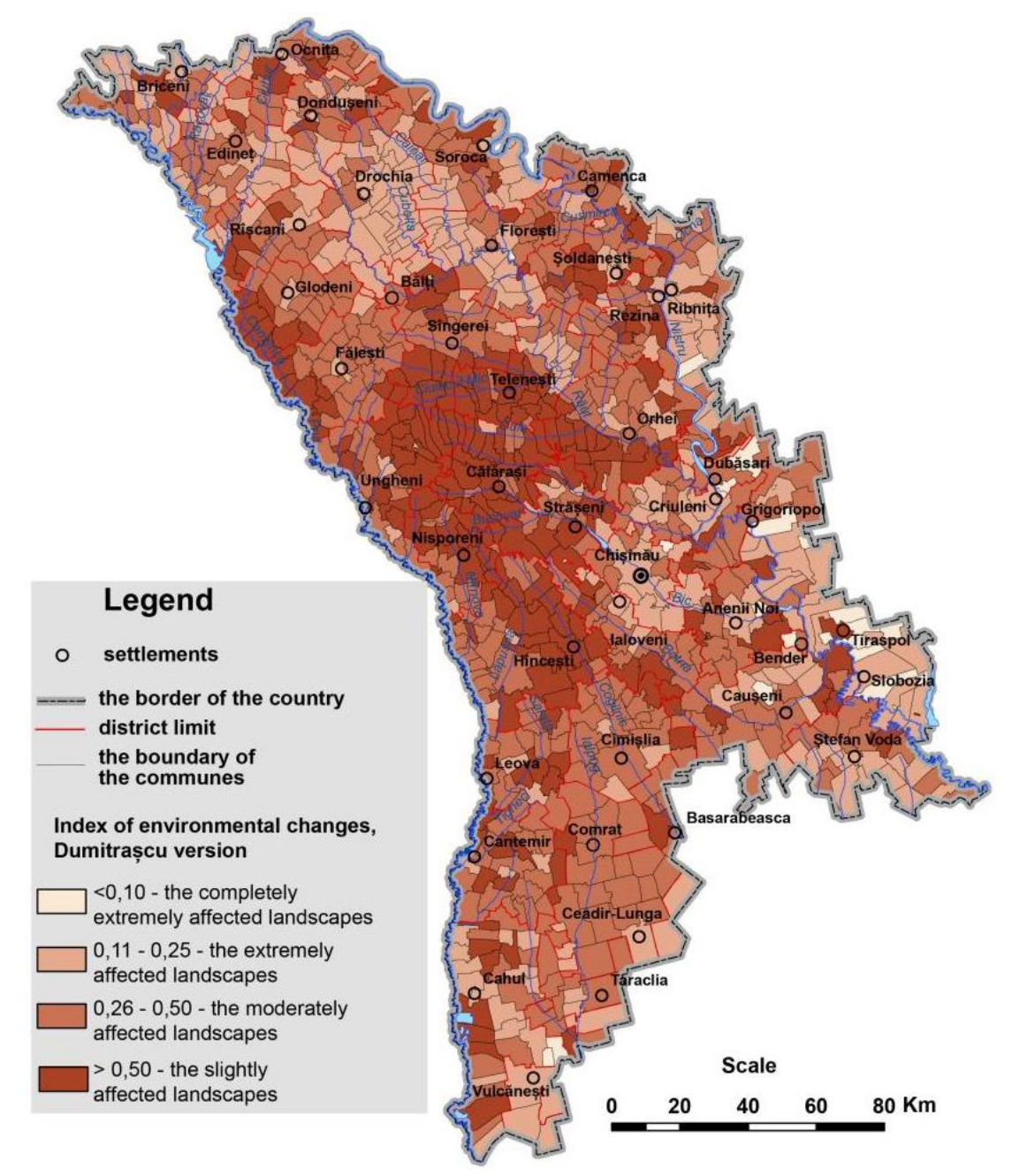

Figure 5. Index of environmental changes, Dumitrașcu version (IE.Ch.D), 2020 
Another heavily modified region is the Steppe Plain of Bălți (Lower Cubolta Steppe Plain). As an example, 22 communes from Drochia region (over $3 / 4$ of the total number) have the value $\mathrm{I}_{\mathrm{E} . \mathrm{Ch} . \mathrm{D}}<0.25$, representing landscapes that are extremely and heavily affected by agricultural activities. It should be mentioned that Drochia region has the largest share $(72 \%)$ of arable land in the country. A high degree of environmental transformation is also registered in the Northern Moldavian Plateau - in Edinet region 15 communes have extremely affected landscapes, and in Briceni region - 14 communes. A considerable number of communes with extremely and completely affected landscapes are also registered in the Ialpug Steppe Plain area (Gagauzia Administrative Territorial Unit and Taraclia region), the Alluvial Plain of the Lower Dniester River (Figure 5). The landscapes with the slightly affected ecological balance (IE.Ch.D $>0.50$ ) make up to approximately $28 \%$, being present in central part of Codrii or Codrii Bâcului (Scoreni, Căpriana and Lozova, Rădenii Vechi, Stolniceni, Bălceana, Cigârleni, Buda communes), Codrii Orheiului (Vatici and Teleșeu communes), Codrii Tigheciului (Haragâș, Toceni, Lunguța communes, etc.). In most of these communes the forest landscapes exceed $35 \%$.

\section{Conclusions}

The dynamics of geographical landscapes on the territory of the Republic of Moldova during the last 20 years had undergone some considerable qualitative changes. Overall, there is a decrease in anthropogenic load on landscapes, which is due, almost exclusively, to depopulation processes (decrease in the number of population by 328.6 thousand inhabitants and its density by about $10 \%$ ). Most categories of landscapes with an increased ecological value had diminished (areas covered with forests - by 6.5 thousand ha, and those with meadows - by 40.5 thousand ha), and those with low ecological value were extended (arable lands - by 17.8 thousand ha, and those occupied by buildings - by 3.9 thousand ha).

Thus, all the analysed pressure indicators showed a decrease in the reference period: index of naturality of the landscapes- from 0.125 to 0.123 ; the environmental changes index (Maruszczak version) - from 3.4 to 3.16 and the environmental changes index (Dumitrașcu version) - from 0.38 to 0.36 .

\section{References}

1. Cadastrul funciar al Republicii Moldova (general) pentru anul 2020. Agenția Relații Funciare și Cadastru. https://www.legis.md/cautare/getResults?doc_id=121917\&lang=ro

2. Cadastrul funciar al Republicii Moldova (general și pe comune) pentru perioada 2001-2020. Agenția Relații și çu Cadastru. https://arfc.gov.md/content/cadastrul-funciar-2010-2019

3.https://statbank.statistica.md/PxWeb/pxweb/ro/20\%20Populatia\%20si\%20procesele\%20dem ografice/20\%20Populatia\%20si\%20procesele\%20demografice_POP_POP010/POP010700. px/table/tableViewLayout1/?rxid=b2ff27d7-0b96-43c9-934b-42e1a2a9a774

4. Muchová Z., Tárníková M. Land cover change and its influence on the assessment of the ecological stability (2018). Applied ecology and environmental research 16(3):2169-2182. http://www.aloki.hu, ISSN 15891623 (Print), 2169-2182 pp, ISSN 17850037 (Online) DOI: http://dx.doi.org/10.15666/aeer/1603_21692182

5. Erdeli G., Cândea M., Braghina C., Costache S., Zamfir D. (1999), Dicţionar de Geografie Umană, Corint, Bucureşti, $391 \mathrm{pp}$.

6. Vijulie I. (2010), Dinamica peisajului rural în Câmpia Boian, Editura Universității din București, ISBN: 978-973-737-855-2, 325 pag.

7. Simulescu D. (2018). The impact of human activities on the environment in the Romanați Plain (Romania), during the postcommunist era. Article in Forum Geografic December 2018. 122-133 pag. DOI: $10.5775 / \mathrm{fg} .2018 .103 . \mathrm{d}$ 
8. Sencovici M., Pehou G. (2016). The Anthropic Pressure on the Landscapes of the Subcarpathian and Piedmont Basin of Dâmboviţa River (Romania). SN - 978-953-51-2513-6, DOI: $10.5772 / 63722$.

9.https://statbank.statistica.md/PxWeb/pxweb/ro/20\%20Populatia\%20si\%20procesele\%20dem ografice/20\%20Populatia\%20si\%20procesele\%20demografice_POP_POP010/POP010700. px/table/tableViewLayout1/?rxid=b2ff27d7-0b96-43c9-934b-42e1a2a9a774

10. Ionuș O., Licurici M., Boengiu S., Simulescu D. (2011). Indicators of the human pressure on the environment in the Bălăcița Piedmont. Forum Geografic, 2011. X (2), 287-294 pag. DOI: $10.5775 / \mathrm{fg} .2067-4635.2011 .013 . \mathrm{d}$

11. Boboc, N., Bejan, I., Muntean, V. (2020). Dinamica structurii sistemelor peisagistice din spațiul Republicii Moldova în secolul XXI. Materialele conferinței științifice naționale cu participare internațională ÎNVĂȚĂMÂNT SUPERIOR: TRADIȚII, VALORI, PERSPECTIVE 29-30 SEPTEMBRIE 2020, VOLUMUL I. Științe Exacte și ale Naturii și Didactica Științelor Exacte și ale Naturii. Chișinău, 2020, CZU: 502.6(478), 77-81 pp.

12. Bejan Iu. (2009), Utilizarea terenurilor în Republica Moldova (monografie), Editura ASEM, ISBN 978-9975-502-3, $166 \mathrm{pp}$.

(C) 2021 by the authors. Licensee UAIC, Iasi, Romania. This article is an open access article distributed under the terms and conditions of the Creative Commons Attribution (CC BY-NC-ND) license (https://creativecommons.org/licenses/by-nc-nd/4.0). 